\title{
SEMA3F Gene
}

National Cancer Institute

\section{Source}

National Cancer Institute. SEMA3F Gene. NCI Thesaurus. Code C106007.

This gene is involved in both cell signaling and axon guidance. 